Neth. J. Pl. Path. 91 (1985) 93-99

\title{
The use of incidence counts for estimation of aphid popula- tions. 1. Minimum sample size for required accuracy
}

\author{
S.A. WARD ${ }^{1}$, R. RABBINGE ${ }^{1}$ and W.P. MANTEL ${ }^{2}$
}

1 Department of Theoretical Production Ecology, Agricultural University, P.O.Box 430, 6700 AK Wageningen, the Netherlands

2 Research Institute for Plant Protection, P.O.Box 9060, 6700 GW Wageningen, the Netherlands

Accepted 22 October 1984

\begin{abstract}
In attempts to reduce the time required for monitoring cereal aphid populations, it has been suggested that direct counting be replaced by the use of incidence counts: estimation of aphid density from the proportion of wheat tillers infested. It is important, however, that the use of this simpler and more rapid method does not result in a loss of accuracy. This paper calculates the minimum sample size (number of tillers to be inspected) required to yield a given accuracy, using the two alternative sampling methods. Over the range of aphid densities close to the economic thresholds for pesticide application, the use of incidence counts does not require a much greater sample size than that needed for direct counting.
\end{abstract}

Additional keywords: cereal aphids, sampling.

Introduction

Currently, plant protection is relying increasingly on flexible supervised control systems. Here, cost-benefit analyses are performed to determine whether pesticide application is needed. Chemicals are then applied only when the pest population exceeds some damage threshold. Clearly, however, such flexibility demands that local population levels can be accurately monitored, so that their future development and damage effects can be predicted.

The most obvious monitoring procedure, direct counting, may become prohibitively time-consuming if the pest is patchily distributed or when it is abundant. It has been suggested, therefore, that instead, some form of presence-absence sampling should be used: assessment of the 'incidence level', the proportion of crop plants infested by the pests (Pielou, 1960; Rabbinge et al., 1980). For such incidence measures to be useful in practice, however, they must be accurate, at least within the range of densities close to the economic threshold.

This paper considers the accuracy of such means of assessing the population density of cereal aphids on winter wheat. It calculates the sample size (the number of wheat tillers to be inspected) for a given level of accuracy in the population estimates. This is then compared with the sample size required for direct counts to yield the same accuracy. 


\section{Incidence and mean density}

Two empirical relations have been used to describe the relation between mean cereal aphid density and the proportion of wheat tillers infested.

1. The Probit model. This relations has been fitted to field data on the density of aphids (Sitobion avenae, Rhopalosiphum padi and Metopolophium॰dirhodum) infesting winter wheat (Rabbinge and Mantel, 1981, 1982), and spring barley (Reitzel, 1982). The relation is:

$\log \mu=a_{1}+b_{1}$ Probit(P)

Where $\mu$ is the mean density, and $\mathrm{P}$ is the proportion of tillers infested, $\mathrm{a}_{1}$ and $\mathrm{b}_{1}$ are constants to be estimated by regression analysis.

2. The Nachman model. This equation, proposed by Nachman (1981), and since then used to describe data on S. avenae infesting winter wheat (Ward et al., in prep. a), has the form

$\log \mu=a_{2}+b_{2} \log \left[\ln \left(\frac{1}{1-P}\right)\right]$

\section{Accuracy of estimates based on incidence counts .}

If $Y$ is a function of $X$, the variance in $y$ (estimates of $Y$ ) based on measurements of $\mathrm{X}$ is given by;

$\operatorname{Var}(\mathrm{y})=\left(\frac{\mathrm{dY}}{\mathrm{dX}}\right)^{2} \operatorname{Var}(\mathrm{x})$

(Topping, 1955).

In the context of the use of incidence counts to estimate mean density,

$\operatorname{Var} \log m=\left(\frac{d \log \mu}{d P}\right)^{2} \operatorname{Var}(p)$,

where $\mathrm{m}$ and $\mathrm{p}$ estimate $\mu$ and $\mathrm{P}$, respectively.

The estimates, $p$, are binomially distributed with mean $P$, and variance

$\operatorname{Var}(\mathrm{p})=\mathrm{P}(1-\mathrm{P}) / \mathrm{n}$

where $\mathrm{n}$ is the sample size. From equations 4 and 5

$\operatorname{Var}(\log m)=\left(\frac{\mathrm{d} \log \mu}{\mathrm{dP}}\right)^{2} \cdot \mathrm{P} \cdot(1-\mathrm{P}) / \mathrm{n}$. 
1. The Probit model. Here, the variance in estimates of $\log \mu$ is calculated as follows.

$\frac{\mathrm{d}(\log \mu)}{\mathrm{dP}}=\frac{\mathrm{b}_{1}}{\mathrm{z}}$

where $z$ is the ordinate of the normal curve.

The variance is thus (substituting equation 7 into equation 6):

$\operatorname{Var}(\log m)=\frac{b_{1}^{2} \cdot P \cdot(1-P)}{z^{2} n}$

(Bliss, 1935).

2. The Nachman model. From equation 2

$\frac{\mathrm{d}(\log \mu)}{\mathrm{dP}}=\frac{\mathrm{b}_{2}}{(\ln 10) \cdot(1-\mathrm{P})[\ln 1 /(1-\mathrm{P})]}$

so the variance is (from equations 6 and 9):

$\operatorname{Var}(\log m)=\frac{b_{2}^{2} \mathrm{P}}{\mathrm{n}(\ln 10)^{2}[\ln (1-\mathrm{P})]^{2}(1-\mathrm{P})}$

(Nachman, 1981).

Accuracy and sample size

The conventional requirement for sampling accuracy is that the standard error of the mean (SEM) does not exceed some fraction (c) of the true mean:

$\mathrm{SEM} \leq \mathrm{c} . \mu$

or

$\operatorname{Var}(m) \leq c^{2} \cdot \mu^{2}$

Since

$\operatorname{Var}(\log m)=\frac{\operatorname{Var}(m)}{\mu^{2}(\ln 10)^{2}}$

(Nachman, 1981), inequality 12 is equivalent to

$\operatorname{Var}(\log m) \stackrel{\circ}{\leq} c^{2} /(\ln 10)^{2}$

We can now calculate the sample sizes needed for incidence counts to yield the required

Neth. J. Pl. Path. 91 (1985) 
accuracy. For the Probit model, substituting equation 8 into equation 14:

$\frac{b_{1}^{2} \cdot P \cdot(1-P)}{z^{2} n} \leq c^{2} /(\ln 10)^{2}$

so the required sample size is given by:

$n \geq \frac{b_{1}^{2} P(1-P)(\ln 10)^{2}}{c^{2} z^{2}}$

The Nachman model gives (from equations 10 and 14):

$\frac{b_{2}^{2} P}{n(\ln 10)^{2}[\ln (1-P)]^{2}(1-P)} \leq c^{2} /(\ln 10)^{2}$

thus,

$\mathrm{n} \geq \frac{\mathrm{b}_{2}^{2} \mathrm{P}}{\mathrm{c}^{2}[\ln (1-\mathrm{P})]^{2}(1-\mathrm{P})}$

\section{Sample size for direct counts}

The variance in $\mathrm{m}$, estimated from direct counting of aphids on a number of tillers is:

$\operatorname{Var}(\mathrm{m})=\frac{\operatorname{Var}(\mathrm{x})}{\mathrm{n}}$,

where $\operatorname{Var}(\mathrm{x})$ is the between-tiller variance in aphid density, and $\mathrm{n}$ is the sample size. From equation 19 and inequality 12 :

$\frac{\operatorname{Var}(\mathrm{x})}{\mathrm{n}} \leq \varsigma^{2} \mu^{2}$,

so

$\mathrm{n} \geq \frac{\operatorname{Var}(\mathrm{x})}{\mathrm{c}^{2} \mu^{2}}$

It has been shown that in many species, the spatial variance can be related to the mean density according to an empirical power law (Taylor, 1961; Taylor et al., 1978):

$\operatorname{Var}(\mathrm{x})=\mathrm{a}_{3} \mu^{\mathrm{b}_{3}}$

If this relation holds, substitution of equation 22 into inequality 21 gives:

$\mathrm{n} \geq \frac{\mathrm{a}_{3} \mu^{\mathrm{b}_{3}-2}}{\mathrm{c}^{2}}$ 
Table 1. Published estimates of the parameters of equations 1, 2 and 22, for cereal aphids on winter wheat.

\begin{tabular}{llrl}
\hline Equation & Parameter & Value & Source \\
1 & & & \\
& $a_{1}$ & -3.066 & From regressions of \\
2 & $b_{1}$ & 0.662 & Rabbinge and Mantel (1981) \\
& $a_{2}$ & 0.331 & Ward, S.A., Chambers, R.J., Sunderland, K. \\
& $b_{2}$ & 1.132 & and Dixon, A.F.G. (in prep. a) \\
& $a_{3}$ & 3.327 & Ward, S.A., Chambers, R.J. Sunderland, K. \\
& $b_{3}$ & 1.427 & and Dixon, A.F.G. (in prep. b) \\
\hline
\end{tabular}

(Ward, S.A., Chambers, R.J., Sunderland, K. and Dixon, A.F.G., in prep. b)

\section{A numerical example: cereal aphids on winter wheat}

This section uses published sets of parameters for equations 1, 2 and 22 (Table 1). The values of $a_{1}$ and $b_{1}$ are as calculated for counts of total aphid density (Rabbinge and Mantel, 1981). $a_{2}, b_{2}, a_{3}$ and $t_{k 3}$ were estimated by Ward et al. (in prep. a,b) using field data on $S$. avenae. The sample sizes required for $90 \%$ accuracy $(c=0.1)$ are as follows:

1. The Probit model. From equation 16:

$\mathrm{n} \geq \frac{6.62^{2} \mathrm{P}(1-\mathrm{P})(\ln 10)^{2}}{\mathrm{z}^{2}}$

2. The Nachman Model. From equation 18:

$\mathrm{n} \geq \frac{11.32^{2} \mathrm{P}}{(1-\mathrm{P})[\ln (1-\mathrm{P})]^{2}}$

3. Direct counting. From equation 23:

$\mathrm{n} \geq 332.7 \mu^{-0.573}$

(Ward et al., in prep. b).

\section{Results and discussion}

Fig. 1 show's the minimum sample sizes, calculated over a range of aphid densities. Two main features are important. First, the two equations ( 1 and 2 ) describing the relation between density and incidence yield different values for the required sample size. Both equations have been fitted successfully to field data, but the discrepancies revealed in Fig. 1 show that further work is necessary to determine the general applicability of the two functions.

Neth. J. Pl. Path. 91 (1985) 


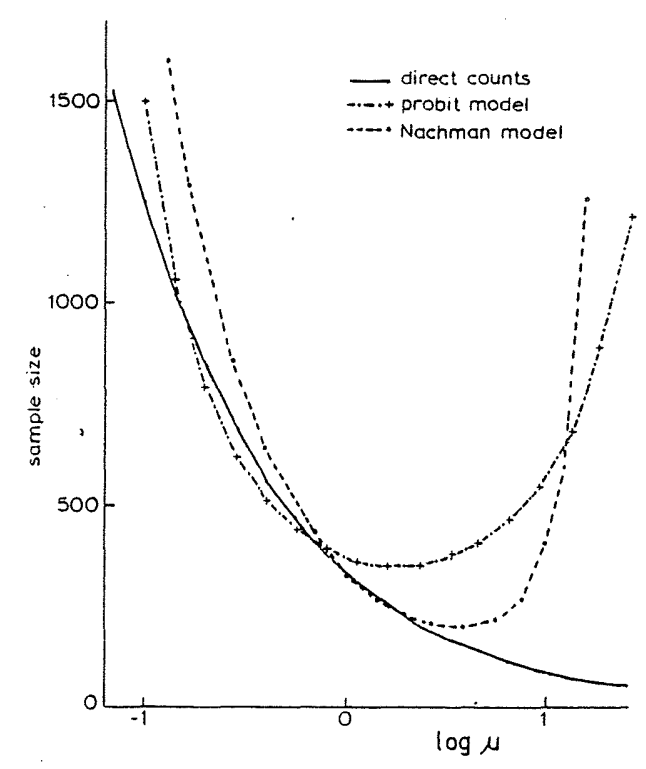

Fig. 1. Minimum sample sizes for the required accuracy: c.v. $=0.1$ of population estimates; using direct counts (counts assuming the Probit $(+-\cdot++)$ and Nachman $(\cdot--\cdot)$ models.

The second main result concerns the difference between the sample sizes required in direct and incidence counts. At very low densities ( $\dot{\mu} \leq 0.1$ aphids/tiller), $\mathrm{n}$ is very large. As $\mu$ increases, the sample size for direct counting declines steadily, while $\mathrm{n}$ for incidence counts falls and then rises sharply. At intermediate levels $(0.1 \leq \mu \leq 10)$, the sample size required for incidence counts is not more than three times that required for more time-consuming direct counts. If $\mu>10$, incidence counts must use an enormous sample size to yield the required accuracy. If, however, there exists a comparable relation between mean density and the proportion of tillers bearing more than ten aphids (Rabbinge and Mantel, in prep.), the sample size curves for incidence counts shift to the right. The density range over which the use of incidence counts is feasible is now greatly extended, and covers the entire range within which the spraying decision must be flexible. (In fact, at most wheat development stages, the threshold for spraying lies between 0.5 and 10 aphids per tiller (Rossing, 1983)). Reducing the level of accuracy required (e.g., setting $c=0.2$ ) greatly reduces the minimum sample size. In selecting a monitoring procedure, therefore, attention must be paid to both the accuracy required and the time involved in sampling. Since the time required for direct counting increases greatly with increasing aphid density, while that for incidence counts (per tiller inspected) is low at all densities, the proper use of incidence measures may lead to considerable savings in the time required for accurate monitoring of aphid populations.

\section{Acknowledgements}

We wish to express our gratitude to Prof. A.F.G. Dixon, Mr B.H.J. van Amersfoort and Mrs H.H. van Laar for their assistance in the preparation of this article. S.A: Ward . received financial support from the International Agricultural Centre, Wageningen. 


\section{Samenvatting}

Het gebruik van bezettingspercentages voor het schatten van bladluispopulatiedichtheid. 1. Minimale steekproefomvang

Teneinde de bemonsteringstijd voor graanluizen te reduceren en een eenvoudige betrouwbare bemonsteringsmethode te ontwikkelen wordt telling van het aantal individuen per halm vaak vervangen door bepaling van het bezettingspercentage. Deze eenvoudige methode mag evenwel niet leiden tot een onaanvaardbaar verlies in nauwkeurigheid. Daarom wordt voor de directe telmethode en de methode met infectiepercentages de minimale monstergrootte bepaald bij een van te voren vastgestelde nauwkeurigheid. Het blijkt dat bij bladluizendichtheden, die dicht bij de economische schadedrempel liggen, de monsters bij de twee methoden niet in grootte behoeven te verschillen.

\section{References}

Bliss, C.I., 1935. The calculation of the dosage-mortality curve. Ann. appl. Biol. 22: 135-167. Nachman, G., 1981. A mathematical model of the functional relationship between density and the spatial distribution of a population. J. Anim. Ecol. 50: 453-460.

Pielou, D.P., 1960. Contagious disiribution in the European red mite, Panonychus ulmi (Koch), and a method of grading population densities from a count of mite-free leaves. Can. J. Zool. 38: 645-653.

Rabbinge, R., Ankersmit, G.W., Carter, N. \& Mantel, W.P., 1980. Epidemics and damage effects of cereal aphids in the Netherlands. Bull. S.R.O.P., 1980/III/4: 99-106.

Rabbinge, R. \& Mantel, W.P., 1981. Monitoring for cereal aphids in winter wheat. Neth. J. Pl. Path. 87: 25-29.

Rabbinge, R.\& Mantel, W.P., 1982. Monitoring and warming systems for cereal aphids in winter wheat. In: Bernard, J. (Ed.), Utilisation du piège à succion en vue de prévoir les invasions aphidiennes. Euraphid, Gembloux, pp. 51-54.

Reitzel, J., 1982. Development of simple registration methods for forecasting cereal aphid infestations, especially in spring barley. In: Bernard, J. (Ed.), Utilisation du piège à succion en vue de prévoir les invasions aphidiennes. Euraphid, Gembloux, pp. 55-56.

Rossing, W.A.H., 1983. Een. stochastisch dynamisch programmeringsmodel voor de optimalisering van bestrijding van bladluizen in wintertarwe met een aanzet tot het kwantificeren van risiko. Int. Med., Vakgroep Theoretische Teeltkunde, Landbouwhogeschool, Wageningen.

Taylor, L.R., 1961. Aggregation, variance and the mean. Nature (Lond.) 189: 732-735.

Taylor, L.R., Woiwod, I.P. \& Perry, J.N., 1978. The density-dependence of spatial behaviour and the rarity of randomness. J. Anim. Ecol. 47: 383-406.

Topping, J., 1955. Errors of observation and their treatment. Institute of Physics Monograph. Chapman and Hall, London. 